\title{
Vanishing metatarsal: a rare manifestation of primary hyperparathyroidism
}

\author{
Vikram Singh Shekhawat, Anil Bhansali
}

Department of Endocrinology, Post Graduate Institute of Medical Education and Research, Chandigarh, India

\section{Correspondence to} Dr Anil Bhansali, anilbhansaliendocrine@gmail. com, ashuendo@gmail.com

Accepted 25 July 2017
CrossMark

To cite: Shekhawat VS, Bhansali A. BMJ Case Rep Published Online First: [please include Day Month Year]. doi:10.1136/bcr-2017220676

\section{DESCRIPTION}

A 31-year-old woman presented with a history of bone pains, difficulty in walking and painless swelling of the left foot for the last 1 year (figure 1). X-ray of the left foot showed multiple lytic lesions in metatarsal bones and the absence of proximal half of shaft of second metatarsal. Biochemistry results revealed corrected serum calcium $11.2 \mathrm{mg} /$ $\mathrm{dL}$, phosphate $2.0 \mathrm{mg} / \mathrm{dL}$, alkaline phosphatase $1049 \mathrm{IU} / \mathrm{mL}$, intact parathyroid hormone (iPTH) $2543 \mathrm{pg} / \mathrm{mL}, 25$-hydroxyvitamin D $16.2 \mathrm{ng} / \mathrm{mL}$, and serum creatinine $0.6 \mathrm{mg} / \mathrm{dL}$. She had no history of pancreatitis or evidence of renal/gall stone disease. The skeletal survey showed multiple osteitis fibrosa cystica (OFC) lesions, pathological fracture of shaft of the left femur and salt and pepper appearance of the skull (figure 2a, b, c). Sestamibi scan revealed right inferior parathyroid adenoma measuring $3.0 \times 2.9 \times 2.2 \mathrm{~cm}$. Based on the above findings, a diagnosis of primary hyperparathyroidism (PHPT) was made and she underwent parathyroid adenectomy. Tumour weighed $4 \mathrm{~g}$ and histopathology was consistent with clear cell parathyroid adenoma.

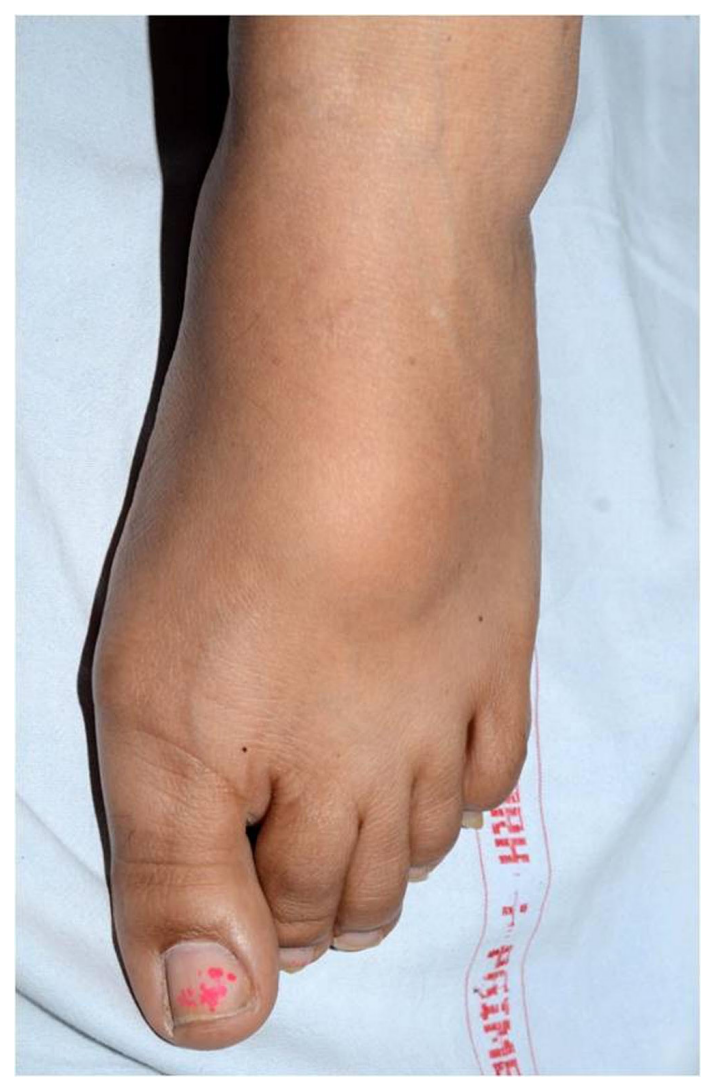

Figure 1 Globular swelling of the left foot.

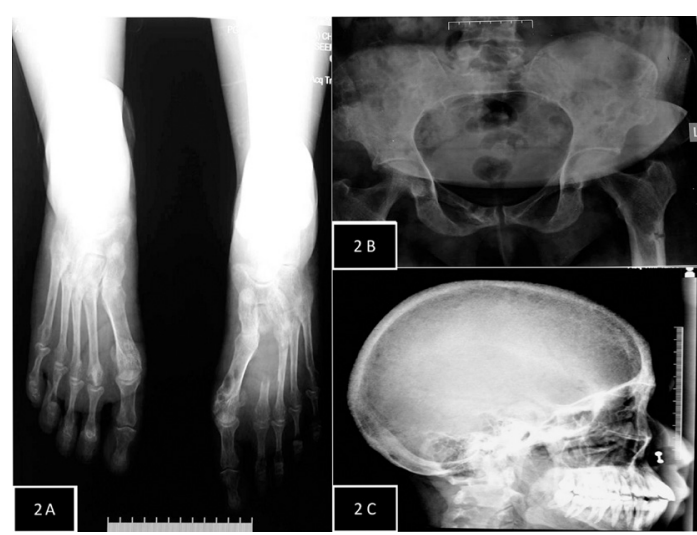

Figure 2 (A) X-ray of both foot showing generalised demineralization of foot bones, multiple lytic lesions (brown tumours) and apparent disappearance of proximal half of second metatarsal of the left foot. (B) X-ray of pelvis showing ill-defined lucencies in bilateral iliac, pubic and ischial bones, and pathological fracture of left femur. (C) X-ray of skull showing 'salt and pepper appearance' of skull.

The classic bone disease of PHPT, OFC is seen in $<2 \%$ of patients. ${ }^{1}$ In severe and long-standing disease, elevated PTH causes increased osteoclast activity resulting in localised alterations in the trabecular pattern, demineralisation and replacement of marrow by loose connective tissue, leading to radiographic disappearance of bones, as was seen in our patient. ${ }^{2}$ They are most commonly seen in flat bones, however, metacarpals and metatarsals are very rarely involved. Differentials of vanishing bone disease besides PHPT include osteomyelitis, Charcot's neuroarthropathy, rheumatoid arthritis, osseous metastasis and Gorham's disease.

Contributors VSS: managed the case and prepared the manuscript. AB: conceived the idea and edited the manuscript.

Competing interests None declared.

Patient consent Obtained.

Provenance and peer review Not commissioned; externally peer reviewed.

\section{Learning points}

- Primary hyperparathyroidism should be considered in the differential diagnosis of vanishing bone disease.

- 'Osteitis fibrosa cystica' is rare and represents severe form of bone disease in primary hyperparathyroidism. 
(c) BMJ Publishing Group Ltd (unless otherwise stated in the text of the article) 2017. All rights reserved. No commercial use is permitted unless otherwise expressly granted.

\section{REFERENCES}

1 Bandeira $\mathrm{F}$, Cusano NE, Silva BC, et al. Bone disease in primary hyperparathyroidism. Arq Bras Endocrinol Metabol 2014:58:553-61.

2 Kemp AM, Bukvic M, Sturgis CD. Fine needle aspiration diagnosis of osteitis fibrosa cystica (brown tumor of bone): a case report. Acta Cytol 2008;52:471-4

Copyright 2017 BMJ Publishing Group. All rights reserved. For permission to reuse any of this content visit http://group.bmj.com/group/rights-licensing/permissions.

BMJ Case Report Fellows may re-use this article for personal use and teaching without any further permission.

Become a Fellow of BMJ Case Reports today and you can:

- Submit as many cases as you like

- Enjoy fast sympathetic peer review and rapid publication of accepted articles

- Access all the published articles

- Re-use any of the published material for personal use and teaching without further permission

For information on Institutional Fellowships contact consortiasales@bmjgroup.com

Visit casereports.bmj.com for more articles like this and to become a Fellow 